ZOOLOGIA 32 (3): 207-214, June 2015

http://dx.doi.org/10.1590/S1984-46702015000300005

\title{
Intra- and inter-annual variations in Chironomidae (Insecta: Diptera) communities in subtropical streams
}

\author{
Diane Nava', Rozane M. Restello' \& Luiz U. Hepp ${ }^{1, *}$
}

\begin{abstract}
${ }^{1}$ Programa de Pós-graduação em Ecologia, Universidade Regional Integrada do Alto Uruguai e das Missões. Avenida Sete de Setembro 1621, 99709-910 Erechim, RS, Brazil.

*Corresponding author. E-mail: luizuhepp@gmail.com
\end{abstract}

\begin{abstract}
The structure and composition of stream benthic communities are strongly influenced by spatial and temporal factors. This study evaluated the intra and inter-annual variations in Chironomidae communities in subtropical streams. The organisms were sampled from 10 small-order streams during the summer and winter of 2010-2012. The number of chironomid specimens sampled was 7,568, distributed in 49 genera. Chironomid abundance and richness varied intra and inter-annually and community composition varied intra-annually (2010 and 2011). Water temperature, total organic carbon, nitrogen, and rainfall were correlated with chironomid community composition. The intra-annual variation of the community was dependent on climatic variations (temperature and rainfall) and changes caused by intensive agricultural use. We conclude that the temporal variation observed in the Chironomidae community correlates with climatic variations (rainfall) and changes in the total organic carbon and total nitrogen, caused by intensive agricultural land use.
\end{abstract}

KEY WORDS. Agriculture impacts; bioindicators; macroinvertebrates; rainfall.

The structure and composition of aquatic communities are influenced by spatial and temporal factors (SUAREZ 2008). Knowing how these factors act on biological communities facilitates the understanding of how local and regional factors influence species occurrence (PofF et al. 2006, SuAREZ 2008). The distribution of benthic macroinvertebrates is affected by factors such as type of substrate (Hepp et al. 2012), habitat characteristics (GALDEAn et al. 2000, Buss et al. 2004), land use (Hepp et al. 2010), and climatic variations over a timescale (SCHEFFER $\&$ VAN Nes 2007). Climatic variations have decisive effects on the distribution of benthic organisms (SмITH et al. 2003) and can occur at different timescales, both intra-annual (seasons) and inter-annual (between years).

Chironomidae (Insecta: Diptera) occur in great abundance and high diversity in most aquatic ecosystems in all continents (Epler 2001, Ferrington 2008). They play an important role in the food web of aquatic communities, establishing links between producers and consumers, as well as participating in nutrient cycles (Henriques-Oliveira et al. 2003). Chironomids are tolerant to various changes in the environment (Rosin \& TAKEDA 2007, Restello et al. 2012), and depending on the species, they may display negative or positive responses to human impacts (FERRINGTON 2008).

Chironomid communities can be effected by the integrity of the riparian zone. The state and the extent of the riparian vegetation correlates with differences in the abundance, richnness, and composition of chironomid communities in streams (SENSOLo et al. 2012). For instance, suppression of the riparian vegetation results in decreased overall diversity and increased numbers of tolerant taxa (AL-SHAMI et al. 2010a). Different chironomids inhabit different habitats and substrates (SAnseverino \& Nessimian 2001) although they are most frequent in heterogeneous and stable environments, where they attain high diversity (RosA et al. 2011, 2013).Temporal variations in biological communities are mainly linked to climate-related changes (e.g., temperature and rainfall). Climate affects ecological processes such as competition, predation and recruitment (GrEsENs et al. 2007). In addition to climatic factors, temporal variations in the structure and composition of chironomid communities may reflect the biological characteristics of the species that compose these communities (Heinis \& Davids 1993, Siqueira et al. 2008) or temporal changes in physical and chemical characteristics (AL-SHAMI et al. 2010b). Natural disturbances, such as spates caused by increased rainfall in human-impacted areas may carry chemicals from adjacent areas to the streams, thus affecting chironomid communities (Gresens et al. 2007).

In this study, the intra- and inter-annual variation of Chironomidae communities in subtropical streams was assessed over three years. We tested the hypothesis that environmental factors related to human activities may be important in structuring communities in streams. Thus, the objectives of this study were (1) to evaluate the intra and inter-annual variations in Chironomidae communities and (2) to determine whether these temporal variations are associated with environmental factors.

2015 | Sociedade Brasileira de Zoologia | www.sbzoologia.org.br | www.scielo.br/zool All content of the journal, except where identified, is licensed under a Creative Commons attribution-type BY-NC. 


\section{MATERIAL AND METHODS}

This study was conducted in the upper portion of the Uruguay River Basin in southern Brazil $\left(27^{\circ} 12^{\prime} 59^{\prime \prime}\right.$ and $28^{\circ} 00^{\prime} 47^{\prime \prime S}, 52^{\circ} 48^{\prime} 12^{\prime \prime}$ and $51^{\circ} 49^{\prime} 34^{\prime \prime} \mathrm{W}$, Fig. 1). The region is characterized by a subtropical climate (Koppen Cfb) with average annual rainfall of $1912.3 \mathrm{~mm}$ and average annual temperature of $17.6^{\circ} \mathrm{C}$. The vegetation is a subtropical forest mix. It is mostly composed of species with tropical-subtropical distribution in the Upper Uruguay, and Araucaria Forest with a predominance of Araucaria (Oliveira-Filho et al. 2015). The predominant land use is intensive agricultural practice $(\sim 77 \%$ of the total area), with soybeans, corn, wheat crops, and large forested areas (DECiAn et al. 2009). Thus, all 10 selected streams are embedded in a complex agricultural matrix. All streams studied were small-order streams ( $<3$ rd order) and had similar limnological characteristics. The average percentage of vegetation in the riparian zone of the streams was 23\% (range 11-49\%).

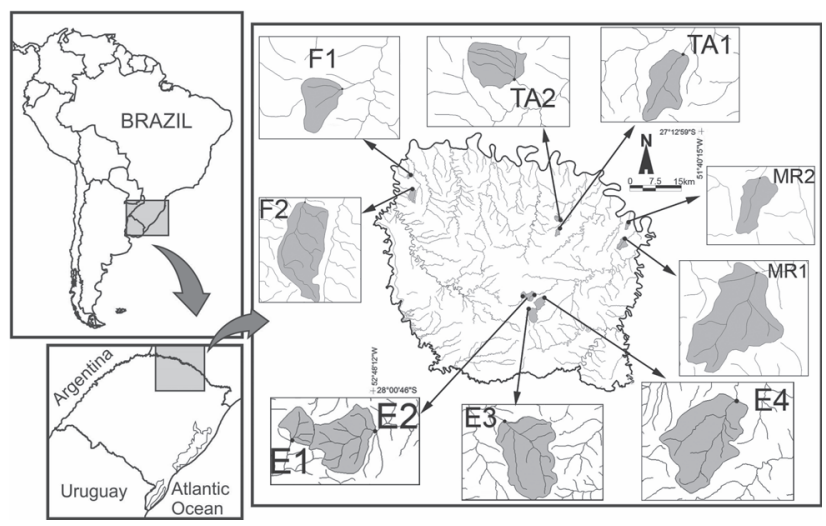

Figure 1. Geographical location of sampling sites at Alto Uruguay region, RS. F: Faxinalzinho, TA: Três Arroios, ERE: Erechim, MR: Marcelino Ramos.

We obtained the following variables from each stream: water temperature, turbidity, conductivity, total dissolved solids, dissolved oxygen and $\mathrm{pH}$, with the aid of a multiparameter analyser HORIBA ${ }^{\circledR}$ U50. A Shimadzu ${ }^{\circledR}$ TOC-VCSH analyzer was used to measure total organic carbon (TOC) and total nitrogen.

Chironomidae larvae were collected in August (winter) and December (summer) of the years 2010, 2011 and 2012. At each stream, three sampling units were obtained with a Surber sampler (mesh $250 \mu \mathrm{m}$, area $0.09 \mathrm{~m}^{2}$ ) on a rock substrate. The material was fixed in the field using $80 \%$ alcohol. In the laboratory, Chironomidae larvae were dipped in a of $10 \%$ bleach solution of potassium hydroxide for 24 hours. Individuals were then mounted on semi-permanent slides with Hoyer solution and were identified under optical microscope with a magnifi- cation of 1,000 times. Specimens were identified at the genus level using the identification keys of Trivinho-STrixino \& STRIXINO (1995) and Trivinho-STrixino (2011).

To assess the intra- and inter-annual variations in abiotic variables Multivariate Analysis of Variance (MANOVA) was used. Variations in chironomid abundance and richness between the seasons (intra-annual) and between the years (interannual) were evaluated using a repeated measure Analysis of Variance (RM-ANOVA). Non-Metric Multidimensional Scaling (NMDS) (KrUSKal 1964) was used to order the chironomid communities. The NMDS was performed with a biological matrix based on the presence or absence of genera in each stream using the Jaccard index. The relationship between environmental and biological data was tested by fitting vectors of environmental variables to the NMDS ordination (function 'envfit' of the vegan package). Analysis of Similarity (ANOSIM) was used to evaluate the level of segregation in community composition between years and within years,. All analyses were performed using R software (R CORE TEAM 2013) with the 'vegan' package (OKSANEN et al. 2013).

\section{RESULTS}

The studied streams have well-oxygenated $(10.85 \pm 2.51$ $\left.\mathrm{mg} \mathrm{L}^{-1}\right)$, slightly acidic water $(\mathrm{pH} 6.62 \pm 0.22)$ with electrical conductivity of $0.030 \pm 0.059 \mathrm{mS} \mathrm{cm}^{-1}$ (mean of three years). The highest average turbidity was recorded in summer (11.75 $\pm 4.90 \mathrm{NTU})$. However, the highest average total organic carbon was recorded in winter $\left(218.34 \pm 216.16 \mathrm{mg} \mathrm{L}^{-1}\right)$ (Table 1$)$. The total organic carbon was very high in the winter of 2011 (Table 1). The highest average monthly rainfall occurred in $2011(172.20 \pm 85.16 \mathrm{~mm})$ followed by $2010(122.6 \pm 101.7$ $\mathrm{mm}$ ) and 2012 (36.7 $\pm 60.0 \mathrm{~mm}$; Fig. 2). However, in 2010 and 2012there was as much rainfall in the winter and the summer. In 2011, the difference in rainfall between the winter and summer seasons was ca. $150 \mathrm{~mm}$. Overall, the abiotic variables differed among the years and between the seasons $\left(\mathrm{F}_{(2,56)}=18.22\right.$, $\mathrm{p}=0.001$ and $\mathrm{F}_{(1,56)}=25.10, \mathrm{p}=0.001$, respectively, Table 2).

We obtained a total of 7,568 chironomid larvae distributed in 49 genera. The highest abundance was recorded in 2012 $(3,304$ larvae, $43.7 \%$ of the total), followed by 2011 (2,430 larvae, $32.1 \%)$ and 2010 (1,834 larvae, $24.2 \%)$. In two of the three years studied (2010 and 2012, Fig. 3, Table 3) chironomids were more abundant in the winter. The greatest number of chironomid genera (43 genera) was identified in 2011, followed by 2012 (33 genera) and 2010 (25 genera). Thus, abundance varied intra-annually while richness varied intra- and inter-annually (Table 3, Fig. 4).

Among the genera identified, Pentaneura Philippi, 1865, Polypedilum Kieffer, 1912, and Rheotanytarsus Thienemann \& Bause in Bause, 1913 were the most frequent in the samples. Aedokritus Roback, 1958, Antillocladius Saether, 1981, Denopelopia Roback \& Rutter, 1988, Djalmabatista Fittkau, 1968, 
Table 1. Mean and standard deviation of limnological variables quantified the drainage areas of the 10 studied streams in the region Alto Uruguay Rio Grande Sul, in the period 2010-2012.

\begin{tabular}{|c|c|c|c|c|c|c|}
\hline \multirow{2}{*}{ Variables } & \multicolumn{2}{|c|}{2010} & \multicolumn{2}{|c|}{2011} & \multicolumn{2}{|c|}{2012} \\
\hline & Summer & Winter & Summer & Winter & Summer & Winter \\
\hline Water temperature $\left({ }^{\circ} \mathrm{C}\right)$ & $20.72 \pm 0.87$ & $15.05 \pm 1.84$ & $21.45 \pm 3.03$ & $14.40 \pm 1.57$ & $22.78 \pm 1.98$ & $16.31 \pm 1.79$ \\
\hline $\mathrm{pH}$ & $6.87 \pm 0.84$ & $6.45 \pm 0.56$ & $6.45 \pm 0.59$ & $6.89 \pm 0.79$ & $6.71 \pm 0.43$ & $6.37 \pm 0.48$ \\
\hline Electrical Conductivity $\left(\mathrm{mS} \mathrm{cm}^{-1}\right)$ & $0.05 \pm 0.03$ & $0.05 \pm 0.02$ & $0.08 \pm 0.04$ & $0.051 \pm 0.02$ & $1.52 \pm 4.59$ & $0.06 \pm 0.03$ \\
\hline Turbidity (UNT) & $13.37 \pm 17.26$ & $3.07 \pm 8.99$ & $6.25 \pm 2.82$ & $8.46 \pm 5.05$ & $15.65 \pm 19.87$ & $8.85 \pm 5.40$ \\
\hline $\mathrm{DO}\left(\mathrm{mg} \mathrm{L}^{-1}\right)$ & $10.38 \pm 1.06$ & $8.36 \pm 0.90$ & $9.54 \pm 2.57$ & $9.49 \pm 0.73$ & $11.92 \pm 3.15$ & $15.39 \pm 1.67$ \\
\hline TDS (mg L-1) & $0.04 \pm 0.02$ & $0.03 \pm 0.01$ & $0.05 \pm 0.03$ & $0.03 \pm 0.01$ & $0.04 \pm 0.02$ & $0.03 \pm 0.02$ \\
\hline Nitrogen $\left(\mathrm{mg} \mathrm{L}^{-1}\right)$ & $15.66 \pm 3.37$ & $6.36 \pm 2.80$ & $0.44 \pm 0.47$ & $1.32 \pm 0.68$ & $1.13 \pm 0.89$ & $1.05 \pm 0.69$ \\
\hline TOC $\left(\mathrm{mg} \mathrm{L}^{-1}\right)$ & $17.14 \pm 5.35$ & $25.05 \pm 21.80$ & $83.90 \pm 39.06$ & $451.76 \pm 100.39$ & $61.28 \pm 58.23$ & $178.21 \pm 50.15$ \\
\hline
\end{tabular}

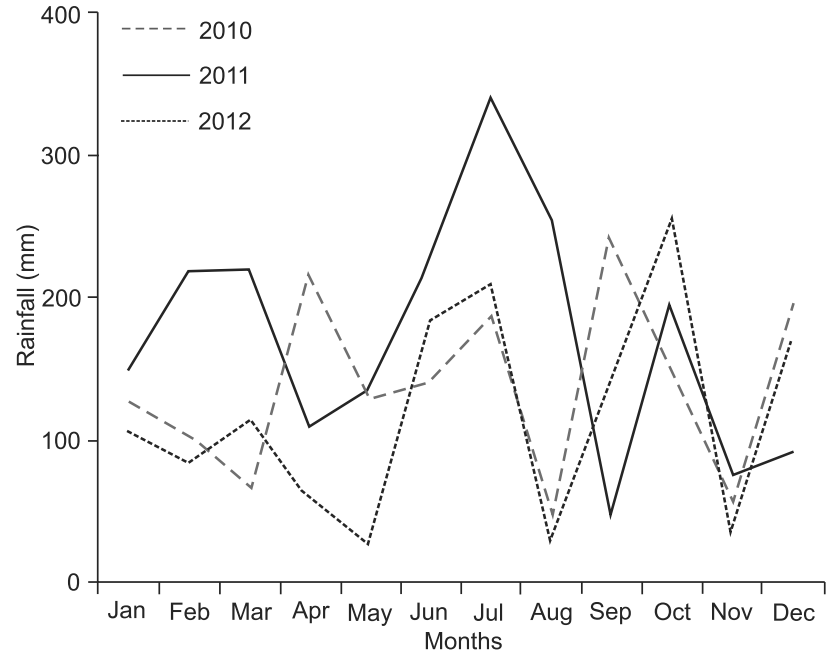

Figure 2. Monthly rainfall in the years 2010, 2011 and 2012 at Alto Uruguay region, RS. The horizontal lines indicate the annual average for the respective years (INMET).
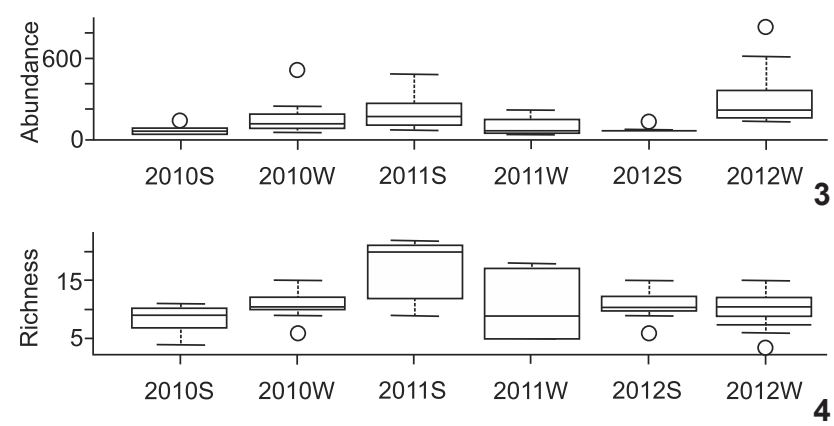

Figures 3-4. Box-plot (median and quartiles) showing the variation of (3) and abundance (4) wealth of inter-annual chironomid larvae (2010, 2011 and 2012) and intra-annual (summer: S, winter: $W$ ) in subtropical streams.
Table 2. MANOVA results for limnological intra and inter-annual among the studied streams were considered as factors the years studied (inter-annual) and the seasons (intra-annual).

\begin{tabular}{lrcccc}
\hline & DF & SS & MS & F & $\mathrm{p}$ \\
\hline Season & 1 & 1.013 & 1.013 & 25.101 & 0.001 \\
Year & 2 & 1.471 & 0.735 & 18.225 & 0.001 \\
Residuals & 56 & 2.260 & 0.040 & 0.476 & \\
\hline Total & 59 & 4.744 & & & \\
\hline
\end{tabular}

Table 3. Repeated measures ANOVA results for the variation in the abundance (log) and richness of Chironomidae community between seasons and among years at 10 stream sites in Alto Uruguay region, Rio Grande Sul.

\begin{tabular}{lrrrr}
\hline & DF & \multicolumn{1}{c}{ SS } & \multicolumn{1}{c}{$\mathrm{F}$} & \multicolumn{1}{c}{$\mathrm{p}$} \\
\hline Abundance (log) & & & & \\
$\quad$ Year & 2 & 1.01 & 0.75 & 0.477 \\
Seasons & 1 & 4.73 & 7.04 & 0.010 \\
$\quad$ Year:Seasons & 2 & 32.22 & 23.97 & $<0.001$ \\
$\quad$ Residuals & 54 & 36.30 & & \\
\hline Richness & & & & \\
$\quad$ Year & 2 & 235.90 & 8.44 & $<0.001$ \\
Seasons & 1 & 43.35 & 3.10 & 0.008 \\
$\quad$ Year:Seasons & 2 & 237.90 & 8.51 & $<0.001$ \\
Residuals & 54 & 754.50 & & \\
\hline
\end{tabular}

Manoa Fittkau, 1963, Paracladius Hirvenoja, 1973, Paramerina Fittkau \& Stur, 1997, and Pseudochironomus Riethia Malloch, 1915 occurred only in winter, while Endotribelos Grodhaus, 1987, Microchironomus Kieffer, 1918, Parapentaneura Stur, Fittkau \& Serrano, 2006, and Ubatubaneura Wiedenbrug \& TrivinhoStrixino, 2009 occurred only in summer (Table 4). Community composition was similar between seasons when the three years were analysed together (ANOSIM, R $=-0.01, \mathrm{p}=0.596$, 

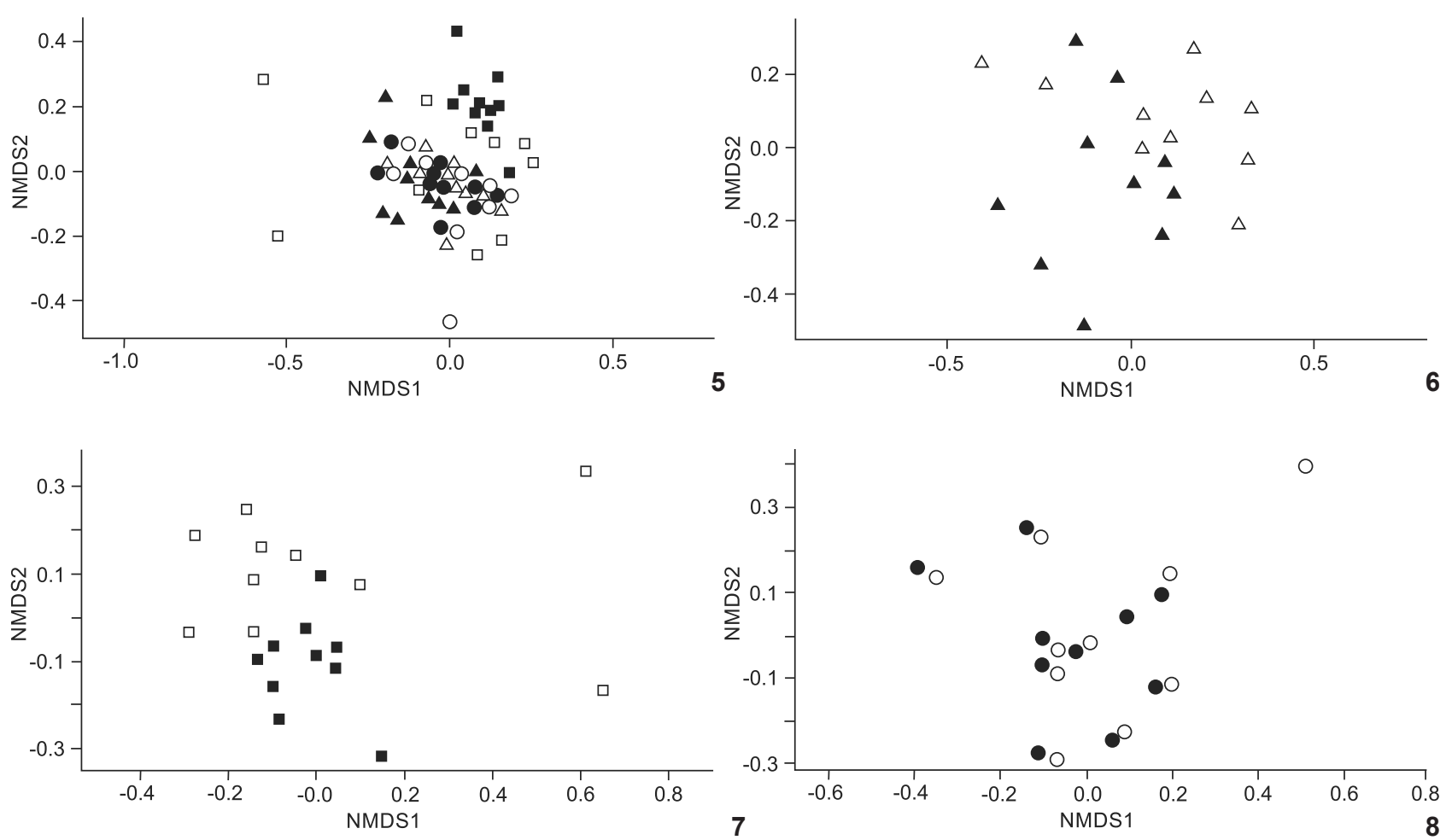

Figures 5-8. Non-Metric Multidimensional Scaling Analysis (NMDS) of the temporal distribution of chironomid community in subtropical streams. (5) inter-annual distribution (2010, 2011, 2012), (6) intra-annual distribution for 2010, (7) intra-annual distribution for 2011, (8) intra-annual distribution for 2012. Open symbols: winner, closed symbols: summer.

Figs. 5-8). However, the generi composition showed segregation between summer and winter in 2011 (ANOSIM, $\mathrm{R}=0.32$, $\mathrm{p}=0.001)$ and 2010 (ANOSIM, $\mathrm{R}=0.12, \mathrm{p}=0.034)$, but not in 2012 (ANOSIM, R = -0.09, $\mathrm{p}=0.976$ ) (Figs. 5-8).

The environmental variables that were correlated with the scores of the first two NMDS dimensions were those that variated seasonally (temperature), human activities (total organic carbon and nitrogen) and rainfall (Table 5). When data from all years were pooled, the community composition correlated with $\mathrm{C}: \mathrm{N}$ ratio $(\mathrm{r}=0.09, \mathrm{p}=0.05)$ and rainfall $(\mathrm{r}=0.11$, $\mathrm{p}=0.04)$. Moreover, in 2010, the NMDS scores showed significant correlation with temperature $(\mathrm{r}=0.31, \mathrm{p}=0.04)$ and nitrogen $(r=0.31, p=0.03)$. In 2011 there was a relationship between water temperature $(\mathrm{r}=0.47, \mathrm{p}=0.004)$, nitrogen $(\mathrm{r}=$ $0.42, \mathrm{p}=0.009)$, TOC $(\mathrm{r}=0.35, \mathrm{p}=0.02)$ and rainfall $(\mathrm{r}=0.30$, $\mathrm{p}=0.03)$. In 2012 there was no correlation with any environmental variable (Table 5).

\section{DISCUSSION}

Chironomidae abundance and generic richness varied either intra-annually (between seasons) and inter-annually (between years). In our study, the abundance of individuals and number of chironomid genera were associated with limnologi- cal characteristics. The effect of these characteristics on the chironomid community may have occurred in association with a significant rainfall event in 2011. Increased precipitation causes changes in aquatic ecosystems, such as changes in the physical and chemical characteristics of the water, as well as changes in the distribution of communities (SмITH et al. 2003). When rainfall increases, chemical compounds present in the soil are dragged into the streams and cause changes in the abundance, richness, and composition of chironomid communities (Gresens et al. 2007). The effect of runoff in this study was especially observed in TOC concentrations in the winter of 2011.

In 2010 and 2012 rainfall was normal with respect to historical records. Streams and their chironomid communities were stable as a result of this. Rainfall increases the amount of water and unstable and homogeneous substrates into the streams (RosA et al. 2013, Salles \& Ferreira-Junior 2014). Therefore, the increased rainfall (2011) during the study period was an important contributor to the observed variations in inter-annual richness. Fluctuations in water regimen allow great habitat diversification, i.e. more tolerant species can occupy distinct regions of the drainage area, in addition to changing the limnological characteristics of streams (Shuvart et al. 2005, Aburaya \& Callil 2007, Roque et al. 2007). SiLvA et al. (2014) also observed that Chironomidae diversity was higher during the years when the abiotic charac- 
Table 4. Chironomidae identified intra-annual (2010-2012) and inter-annual (summer and winter) in subtropical streams.

\begin{tabular}{|c|c|c|c|c|c|c|}
\hline & \multicolumn{2}{|c|}{2010} & \multicolumn{2}{|c|}{2011} & \multicolumn{2}{|c|}{2012} \\
\hline & $S$ & $\mathrm{~W}$ & $\mathrm{~S}$ & $\mathrm{~W}$ & $S$ & $\mathrm{~W}$ \\
\hline \multicolumn{7}{|l|}{ Chironominae } \\
\hline Aedokritus Roback, 1958 & & & & * & & \\
\hline Caladomyia Säwedal, 1981 & * & * & * & & * & * \\
\hline Chironomus Meigen, 1803 & & & * & * & & \\
\hline Dicrotendipes Kieffer, Epler, 1988 & & & * & * & & \\
\hline Endotribelos Grodhaus, 1987 & & & * & & & \\
\hline Goeldichironomus Fittkau, 1965 & * & & * & & & \\
\hline Manoa Fittkau, 1963 & & & & * & & \\
\hline Microchironomus Kieffer, 1918 & & & * & & & \\
\hline Parachironomus Lenz, 1921 & * & & * & & & \\
\hline Paratanytarsus Thienemman \& Bause, 1951 & & & * & * & & \\
\hline Paratendipes Kieffer, 1911 & * & * & * & * & * & * \\
\hline Phaenopsectra Kieffer, 1921 & * & & * & * & & \\
\hline Polypedilum Kieffer, 1912 & * & * & * & * & * & * \\
\hline Pseudochironomus, Riethia Malloch, 1915 & & * & * & * & * & * \\
\hline Rheotanytarsus Thienemann \& Bause, 1913 & * & * & * & * & * & * \\
\hline Saetheria Saether, 1983 & & & * & & & \\
\hline Stenochironomus Kieffer, 1919 & & & * & & & \\
\hline Tanytarsus Van der Wulp, 1874 & * & * & * & * & * & * \\
\hline Xestochironomus Sublette \& Wirth, 1972 & & & * & & & \\
\hline Zavreliella Kieffer, 1920 & & & * & * & & \\
\hline \multicolumn{7}{|l|}{ Orthocladiinae } \\
\hline Antillocladius Saether, 1981 & & & & * & & \\
\hline Cardiocladius Kieffer, 1912 & & & * & * & & \\
\hline Corynoneura Winnertz, 1846 & * & * & * & * & * & * \\
\hline Cricotopus Van der Wulp, 1874 & * & * & * & & * & * \\
\hline Cricotopus, Orthocladius Lopescladius Oliveira, 1967 & * & * & * & * & * & * \\
\hline Gymnometriocnemus Goetghebuer, 1932 & * & * & * & & & \\
\hline Lopescladius Oliveira, 1967 & * & * & * & & * & * \\
\hline Metriocnemus Kieffer 1921 & & & * & * & & \\
\hline Nanocladius Kieffer, 1912 & * & * & * & * & * & * \\
\hline Onconeura Andersen \& Saether, 2005 & * & * & * & * & * & * \\
\hline Orthocladiinae A Kieffer, 1911 & & & * & * & & \\
\hline Orthocladiinae B Kieffer, 1911 & & & * & * & & \\
\hline Paracladius Hirvenoja, 1973 & & & * & & & \\
\hline Parakiefferiella Thienneman 1926 & & * & * & * & * & * \\
\hline Parametriocnemus Goetghebuer, 1932 & * & * & * & * & * & * \\
\hline Paraphaenocladius Thienemann, 1924 & & & * & * & & \\
\hline Rheocricotopus Thienemann \& Harnisch, 2004 & * & * & * & * & * & * \\
\hline Thienemannia Kieffer, 1909 & & & * & * & & \\
\hline Thienemanniella Kieffer, 1911 & & * & * & * & * & * \\
\hline $\begin{array}{l}\text { Ubatubaneura Wiedenbrug \& Trivinho- } \\
\text { Strixino, } 2009\end{array}$ & & & * & & & \\
\hline \multicolumn{7}{|l|}{ Tanypodinae } \\
\hline Denopelopia Roback e Rutter (1988) & & & & * & & \\
\hline Djalmabatista Fittkau (1968) & & & * & & & \\
\hline Hudsonimyia Roback, 1979 & & & * & * & & \\
\hline Labrudinia Fittkau, 1962 & & & * & & & \\
\hline Larsia Roback \& Coffman (1989) & & & * & * & & \\
\hline Nilotanypus Kieffer, 1923 & * & * & * & * & * & * \\
\hline Paramerina Stur and Fittkau, 1997 & & & & * & & \\
\hline Parapentaneura Stur, Fittkau \& Serrano, 2006 & & & * & & & \\
\hline Pentaneura Philippi, 1865 & * & * & * & ${ }^{\star}$ & * & * \\
\hline
\end{tabular}

Table 5. Analysis of the structure between the abiotic data and the biological matrix (NMDS), inter- and intra-annual variation tested from the non-parametric multivariate analysis in subtropical streams.

\begin{tabular}{|c|c|c|c|c|}
\hline & NMDS1 & NMDS2 & R2 & $\mathrm{p}$ \\
\hline \multicolumn{5}{|l|}{2010 to 2012} \\
\hline Water temperature & 0.331 & 0.943 & 0.078 & 0.12 \\
\hline $\mathrm{pH}$ & -0.967 & -0.251 & 0.094 & 0.058 \\
\hline Electrical Conductivity & 0.559 & -0.828 & 0.011 & 0.669 \\
\hline Turbidity & -0.812 & -0.583 & 0.016 & 0.575 \\
\hline DO & -0.168 & -0.985 & 0.088 & 0.088 \\
\hline TDS & -0.125 & 0.992 & 0.042 & 0.285 \\
\hline Nitrogen & -0.999 & 0.043 & 0.041 & 0.287 \\
\hline TOC & -0.968 & -0.247 & 0.004 & 0.907 \\
\hline $\mathrm{C}: \mathrm{N}$ ratio & -0.288 & 0.957 & 0.099 & 0.050 \\
\hline Water velocity & 0.891 & -0.452 & 0.016 & 0.551 \\
\hline Rainfall & -0.847 & -0.531 & 0.110 & 0.041 \\
\hline \multicolumn{5}{|l|}{2010} \\
\hline Water temperature & -0.834 & -0.551 & 0.310 & 0.040 \\
\hline $\mathrm{pH}$ & -0.898 & 0.439 & 0.118 & 0.364 \\
\hline Electrical Conductivity & -0.990 & -0.134 & 0.092 & 0.457 \\
\hline Turbidity & -0.163 & -0.986 & 0.071 & 0.535 \\
\hline DO & -0.426 & -0.904 & 0.285 & 0.064 \\
\hline TDS & -0.880 & -0.473 & 0.111 & 0.378 \\
\hline Nitrogen & -0.711 & -0.702 & 0.316 & 0.039 \\
\hline TOC & -0.609 & 0.792 & 0.284 & 0.057 \\
\hline $\mathrm{C}: \mathrm{N}$ ratio & -0.408 & 0.912 & 0.260 & 0.090 \\
\hline Water velocity & 0.749 & -0.661 & 0.062 & 0.588 \\
\hline Rainfall & -0.695 & -0.718 & 0.051 & 0.626 \\
\hline \multicolumn{5}{|l|}{2011} \\
\hline Water temperature & -0.039 & -0.999 & 0.474 & 0.004 \\
\hline $\mathrm{pH}$ & 0.590 & 0.806 & 0.091 & 0.441 \\
\hline Electrical Conductivity & 0.335 & -0.941 & 0.107 & 0.378 \\
\hline Turbidity & -0.523 & 0.851 & 0.238 & 0.105 \\
\hline DO & -0.271 & 0.962 & 0.065 & 0.527 \\
\hline TDS & 0.342 & -0.939 & 0.110 & 0.371 \\
\hline Nitrogen & -0.328 & 0.944 & 0.426 & 0.009 \\
\hline TOC & 0.113 & 0.993 & 0.352 & 0.021 \\
\hline $\mathrm{C}: \mathrm{N}$ ratio & 0.980 & 0.194 & 0.196 & 0.156 \\
\hline Water velocity & -0.579 & 0.814 & 0.065 & 0.462 \\
\hline Rainfall & 0.134 & 0.990 & 0.309 & 0.036 \\
\hline \multicolumn{5}{|l|}{2012} \\
\hline Water temperature & 0.986 & -0.165 & 0.007 & 0.938 \\
\hline $\mathrm{pH}$ & 0.753 & 0.658 & 0.017 & 0.854 \\
\hline Electrical Conductivity & 0.291 & -0.956 & 0.097 & 0.338 \\
\hline Turbidity & -0.785 & 0.618 & 0.226 & 0.114 \\
\hline DO & 0.947 & 0.320 & 0.006 & 0.949 \\
\hline TDS & 0.917 & 0.397 & 0.023 & 0.832 \\
\hline Nitrogen & 0.948 & 0.315 & 0.012 & 0.903 \\
\hline TOC & 0.142 & 0.989 & 0.075 & 0.543 \\
\hline $\mathrm{C}: \mathrm{N}$ ratio & -0.671 & 0.741 & 0.249 & 0.104 \\
\hline Water velocity & 0.332 & 0.943 & 0.039 & 0.726 \\
\hline Rainfall & 0.705 & 0.708 & 0.019 & 0.855 \\
\hline
\end{tabular}


teristics of their studied lake changed. Rainfall is one abiotic variable that can create favorable conditions for certain species, not only as a function of the new habitat conditions (Bispo et al. 2006). Water temperature affects the metabolism of organisms and the availability of food, causing changes in community composition (Hahn \& Figi 2007, Gray \& Elliott 2009). The highest concentrations of carbon and nitrogen were found in areas with intense human activity (e.g. agricultural practices) (NeILL et al. 2001, SiLvA et al. 2007). Currently, many streams display similar signs of anthropogenic change (mainly as the result of agricultural practices), a phenomenon known as eutrophication of aquatic ecosystems (Galloway et al. 2003, Silveira et al. 2006). The drainage areas of the streams studied were populated with crops and exposed soil (in preparation for cultivation). In these areas, the use of pesticides and fertilizers is high, causing soil contamination particularly when rainfall is intense. These pesticides, plus organic matter and nutrients, are carried into the streams by the rain water.

Organic matter is primarily composed of carbon, but it can be associated with other chemical compounds, such as metals (Ali et al. 2002, Al-Shami et al. 2010a, Sensolo et al. 2012). On the other hand, nitrogen is among the most limiting nutrients to primary productivity and the availability of this nutrient affects the abundance of some aquatic organisms (GALLOWAY et al. 2003). Cricotopus species feed on algae, which in turn are dependent on certain concentrations of dissolved nutrients (SEnsolo et al. 2012). Polypedilum and Rheotanytarsus were the most common organisms in all samples. Studies report that these genera are easily sampled in streams and are reported as cosmopolitan/tolerant (AMorim et al. 2004, MARCheSE et al. 2005, Aburaya \& Callil 2007). Furthermore, the high density of individuals of Rheotanytarsus is due to their eating habits: they are filter-feeding organisms, consuming exclusively organic matter present in the water (Coffman \& Ferrington 1996). Polypedilum species stand out for being tolerant to a wide range of environmental conditions, as they may occur both in sites impacted with organic compounds and in non-impacted sites (Heinis \& Davids 1993, Rosin \& TAKeda 2007).

In conclusion, in small temporal scales, local environmental factors have great relative influence on community composition. On the other hand, in larger timescales, climatic factors generate variation (SILvA et al. 2014). In this study, we observed that in those three years, with semi-annual collecting, intra-annual variations are most evident in the chironomid communities. In this study, the temporal variation of the community was dependent on climatic variations (rainfall) as well as the changes in the TOC and TN caused by intensive agricultural land use.

\section{ACKNOWLEDGMENTS}

DN received financial support from the Program PROSUP/ CAPES. RMR receives financial support from CNPq (Proc. 477274/2011-0 and proc. 475251/2009-1). LUH receives finan- cial support from CNPq (Edital Universal, process 471572/20128) and FAPERGS (process 12/1354-0). The authors thank Rodrigo Fornel for their help editing images, and Adriano Melo and two anonymous reviewers for their suggestions and criticisms.

\section{LITERATURE CITED}

Aburaya FH, Callil CT (2007) Variação temporal de larvas de Chironomidae (Diptera) no Alto Rio Paraguai (Cáceres Mato Grosso, Brasil). Revista Brasileira de Zoologia 24(3): 565572. doi: 10.1590/S0101-81752007000300007

Ali A, Frouz J, Lobinske RJ (2002) Spatio-temporal effects of selected physico-chemical variables of water, algae and sediment chemistry on the larval community of nuisance Chironomidae (Diptera) in a natural and a man-made lake in central Florida. Hydrobiologia 470: 181-193.

Al-Shami SA, Rawi CSM, HassanAhmad A, Nor SAM (2010a) Distribution of Chironomidae (Insecta: Diptera) in polluted rivers of the Juru River Basin, Penang, Malaysia. Journal of Environmental Sciences 22(11) 1718-1727.

Al-Shami SA, Salmah MRC, Hassan AA, Azizah MNS (2010b) Temporal distribution of larval Chironomidae (Diptera) in experimental rice fields in Penang, Malaysia. Journal of Asia-Pacific Entomology 13: 17-22. doi: 10.1016/j.aspen.2009.11.006

Amorim RM, Henriques-Oliveira AL, Nessimian JL (2004) Distribuição espacial e temporal das larvas de Chironomidae (Insecta: Diptera) na seção ritral do rio Cascatinha, Nova Friburgo, Rio de Janeiro, Brasil. Lundiana 5(2): 119-127.

Bispo PC, Oliveira LG, Bini LM, Sousa KG (2006) Ephemeroptera, Plecoptera and Trichoptera assemblages from riffles in mountain streams of central Brazil: environmental factors influencing the distribution and abundance of immature. Brazilian Journal of Biology 66(2): 611-622. doi: 10.1590/ S1519-69842006000400005

Buss DF, Baptista DF, Nessimian JL, Egler M (2004) Substrate specificity, environmental degradation and disturbance structuring macroinvertebrate assemblages inneotropical streams. Hydrobiologia 518(1-3): 179-188. doi: 10.1023/ B:HYDR.0000025067.66126.1c

Coffman WP, Ferrington JR LC (1996) Chironomidae, p. 635-754. In: MerRitt KW, Cummins RW (Eds.). An introduction to the aquatic insects of North America. Dubuque, Kendall, Hunt Publishing.

Decian V, Zanin EM, Henke C, Quadros FR, Ferrari CA (2009) Uso da terra na região Alto Uruguai do Rio Grande do Sul e obtenção de banco de dados relacionado a fragmentos de vegetação arbórea. Perspectiva 33(121): 165-176.

EPLer J (2001) Identification manual for the larval Chironomidae (Diptera) of North and South Carolina. Orlando, Departament of Enviromental and Natural Resources, 526p.

Ferrington LC (2008) Global diversity of non-biting midges (Chironomidae; Insecta-Diptera) in freshwater. Hydrobiologia 595: 447-455. doi: 10.1007/s10750-007-9130-1 
Galdean N, Callisto M, Barbosa Far, Rocha LA (2000) Lotic ecosystems of Serra do Cipó, southeast Brazil: water quality and a tentative classification based on the benthic macroinvertebrate community. Journal Aquatic Ecosystem Health and Management 3: 545-552. doi: 10.1016/S14634988(00)00044-0

Galloway JN, Aber JD, Ersiman JW, Seitzinger SP, Howarth RW, Cowling EB, J Cosby (2003) The Nitrogen Cascade. BioScience 53(4): 341-356. doi: 10.1641/0006-3568(2003)053[0341:TNC]2.0.CO;2

Gray JS, Elliott M (2009) Ecology of Marine Sediments. From Science to Management. Oxford, Oxford University Press, 2nd ed., 225p.

Gresens SE, Belt KT, Tang JA, Gwinn DC, Banks PA (2007) Temporal and spatial responses of Chironomidae (Diptera) and other benthic invertebrates to urban stormwater runoff. Hydrobiologia 575: 173-190. doi 10.1007/s10750-006-0366-y

Hanh NS, Figi R (2007) Alimentação de peixes em reservatórios brasileiros: alterações e consequências nos estágios iniciais de represamento. Oecologia Brasiliensis 4(11): 469-480. doi: 10.4257/oeco.2007.1104.01

HeINIS F, DAvids C (1993) Factors Governing the spatial and temporal distribution of chironomid larvae in the Maarseveen Lakes with special emphasis on the tole of oxygen conditions. Netherlands Journal of Aquatic Ecology 27(1): 21-34.

Henriques-Oliveira AL, Nessimian JL, Dorvillé LFM (2003) Feeding habits of chironomid larvae (Insecta: Diptera) from a stream in the floresta da Tijuca, Rio de Janeiro, Brazil. Brazilian Journal Biology 63(2): 269-281. doi: 10.1590/S1519. 69842003000200012

Hepp LU, Milesi SV, Biasi C, Restello RM (2010) Effects of agricultural and urban impacts on macroinvertebrates assemblages in streams (Rio Grande do Sul, Brazil). Revista Brasileira de Zoologia 27(1): 106-113. doi: 10.1590/S198446702010000100016

Hepp LU, Landeiro VL, Melo AS (2012) Experimental Assessment of the Effects of Environmental Factors and Longitudinal Position on Alpha and Beta Diversities of Aquatic Insects in a Neotropical Stream. International Review of Hydrobiology 97(2): 157-167. doi: 10.1002/iroh.201111405

KrUSKaL JB (1964) Multidimensional caling by optimizing goodness of fit to a nonmetric hypothesis. Psychometrika 9(1): 1-27.

Marchese MR, Watzen KM, Ezcurra-de-Drago I (2005) Benthic invertebrate assemblages and species diversity patterns of the upper Paraguay River. River Research and Applications 21(5): 485-499. doi: 10.1002/rra.814

Neill C, Deegan LD, Cerri CC, Thomaz S (2001) Deforestation for pasture alters nitrogen and phosphorus in small Amazonian streams. Ecological Applications 11(6): 1817-1828. doi: 10.1890/1051-0761(2001)011[1817:DFPANA]2.0.CO;2

Oliveira-Filho AT, Budke JC, Jarenkow JA, Eisenlohr PV, Neves DRM (2015) Delving into the variations in tree species compo- sition e richness across South American subtropical Atlantic and Pampean forests. Journal of Plant Ecology 8(3): 242260. doi: $10.1093 /$ jpe/rtt058

Oksanen J, Blanchet F, Kindt R, Legendre P, O’Hara RG, Simpson GL, Solymos P, Stevens MHH, Wagner H (2013) Vegan: Community Ecology Package. R package, v. 1.17-0. Available online at: http://CRAN.R-project.org/package = vegan [Accessed: 12/11/2013]

Poff NL, Olden JD, Vieira NKM, Finn DS, Simmons MP, KondratiefF BC (2006) Functional trait niches of North American lotic insects: traits based ecological applications in light of phylogenetic relationships. Journal of the North American Benthological Society 25(4): 730-755. doi: 10.1899/08873593(2006)025 [0730:FTNONA]2.0.CO;2

R Core Team (2013) A Language and Environment for Statistical Computing. R Foundation for Statistical Computing. Vienna, ISBN 3-900051-07-0. Available online at: http:// www.R-project.org [Accessed: 12/11/2013]

Restello RM, Hepp lU, Menegatti C, Decian V, henke-oliveira C (2012) Efeito das características da área de drenagem sobre a distribuição de Chironomidae (Diptera) em riachos do Sul do Brasil, p. 324-340. In: SANTos JE, Zanin EM, Moschini LE (Orgs.). Faces da Polissemia da Paisagem - Ecologia, Planejamento e Percepção. São Carlos, Rima, vol. 4.

Roque FO, Trivinho-Strixino S, Milan L, Leite JG (2007) Chironomid species richness in low-order streams in the Brazilian Atlantic Forest: a first approximation through a Bayesian approach. Journal of North American Benthological Society 26(2): 221231.

Rosa BFJV, Vasques M, Alves RG (2011) Structure and spatial distribution of the Chironomidae community in mesohabitats in a first order stream at the Poc'o D'Anta Municipal Biological Reserve in Brazil. Journal of Insect Science 11: 1-13.

Rosa BFJV, Vasques M, Alves RG (2013) Chironomidae (Insecta, Diptera) associated with stones in a first-order Atlantic Forest stream. Revista Chilena de Historia Natural 86: 291-300.

Rosin GC, TAKeda AM (2007) Larvas de Chironomidae (Diptera) da planície de inundação do alto rio Paraná: distribuição e composição em diferentes ambientes e períodos hidrológicos. Acta Scientiarum Biological Sciences 29(1): 57-63. doi: 10.4025/actascibiolsci.v29i1.127

Salles FF, Ferreira-Júnior N (2014) Hábitat e Hábitos, p. 39-49. In: Hamada N, JL Nessimian, Querino RB (Eds.). Insetos aquáticos na Amazônia brasileira: taxonomia, biologia e ecologia. Manaus, INPA, 724p.

Sanseverino AM, Nessimian JL (2001) Haìbitats de larvas de Chironomidae (Insecta, Diptera) em riachos de Mata Atlantica no Estado do Rio de Janeiro. Acta Limnologica Brasiliensia 13: 29-38.

Scheffer M, VAn Nes EH (2007) Shallow lakes theory revisited: various alternative regimes driven by climate, nutrients, depth and lake size. Hydrobiologia 584: 455-466. doi: 10.1007/978-1-4020-6399-2_41 
Sensolo D, Hepp LU, Decian V, Restello RM (2012) Influence of landscape on assemblages of Chironomidae in Neotropical streams. Annales de Limnologie - International Journal of Limnology 48: 391-400. doi: 10.1051/limn/2012031

Shuvartz M, Oliveira LG, Diniz-Filho JAF, Bini LM (2005) Relações entre distribuição e abundância de larvas de Trichoptera (Insecta), em córregos de Cerrado no entorno do Parque Estadual da Serra de Caldas (Caldas Novas, Estado de Goiás). Acta Scientiarum Biological Sciences 27(1): 51-55. doi: 10.4025/actascibiolsci.v27i1.1360

Silva DML, Ometto JPHB, Lobo GA, Lima WP, Scaranello MA, Mazi E, Roch HR (2007) Can Land Use Changes Alter Carbon, Nitrogen and Major Ion Transport in Subtropical Brazilian Streams? Scientia Agricola 64(4): 317-324. doi: 10.1590/ S0103-90162007000400002

Silva JS, Albertoni EF, Silva CP (2014) Temporal variation of phytophilous Chironomidae over a 11-year period in a shallow Neotropical lake in southern Brazil. Hydrobiologia 737(1): 114. doi: 10.1007/s10750-014-1972-8

Silveira MP, Buss DF, Nessimian JL, Baptista DF (2006) Spatial and temporal distribution of benthic macroinvertebrates in southeastern Brazilian river. Brazilian Journal of Biology 66(2): 623-632. doi: 10.1590/S1519-69842006000400006

Siqueira T, Roque FO, Trivinho-Strixino S (2008) Phenological patterns of neotropical lotic chironomids: Is emergence constrained by environmental factors? Austral Ecology 33: 902-910. doi: 10.1111/j.1442-9993.2008.01885.x

Smith H, Wood PJ, Gunn J (2003) The influence of habitat structure e flow permanence on invertebrate communities in karst spring systems. Hydrobiologia 510(1): 53-66. doi: 10.1023/B:HYDR.0000008501.55798.20

SúAREZ YR (2008) Variação espacial e temporal na diversidade e composição de espécies de peixes em riachos da bacia do Rio Ivinhema, Alto Rio Paraná. Biota Neotropica 8(3): 197204. doi: 10.1590/S1676-06032009000100012

Trivinho-STrixino S (2011) Larvas de Chironomidae. Guia de identificação. São Carlos, Departamento de Hidrobiologia, Laboratório de Entomologia Aquática, UFSCar, 371p.

Trivinho-Strixino S, Strixino G (1995) Larvas de Chironomidae (Diptera) do estado de São Paulo: guia de identificação e diagnose dos gêneros. São Carlos, PPG-RRN/UFSCar, 229p.

Submitted: 30 November 2014

Received in revised form: 17 April 2015

Accepted: 2 May 2015

Editorial responsibility: Adriano S. Melo 